\title{
BALANCED LETHALS AND POLYMORPHISM IN RUBUS IDAEUS
}

\author{
D. L. JENNINGS \\ Scottish Horticultural Research Institute, \\ Dundee, Great Britain
}

Received 24.xi.66

\section{INTRODUCTION}

Several writers (Grubb, I922; Lewis, r 939; Jennings, 1964) have commented upon the high frequency with which colonies of Rubus ideus are polymorphic for glabrous and sub-glabrous plants, and though there is less evidence for polymorphism in respect of pigmented and nonpigmented plants, there is evidence that many populations maintain high frequencies of alternative alleles of the gene which determines this difference. These observations on natural populations of Rubus ideus are supported by data from experimental progenies of wild raspberries, and by the results of breeding experiments on certain cultivars believed to be closely related to wild populations (Jennings, 1963). There are two gene loci involved in the inheritance of these differences-the $H: h$ locus, which determines the degree of plant hairiness, and the $T: t$ locus, which determines the presence or absence of red pigment. Haskell (I96o) provides information on their segregation in progenies from 25 samples of wild raspberry fruits collected from scattered parts of Britain, and information on the selfed progenies of 23 cultivars is available from the published work of Grane and Lawrence (I93I), Grubb (1935), Lewis (r939) and from unpublished work by the writer. The information from these sources is summarised in table $\mathrm{r}$.

In most populations selection tends to act towards fixation of the most favourable allele, and so the retention of intermediate allelic frequencies at these loci and the consequent occurrence of polymorphism calls for some explanation. Selection would act in favour of the heterozygotes if for example the genes were each associated with a balanced lethal system, or if there were advantages associated with pleiotropic effects of the recessive genes. Alternating directions of selection would also result in both alleles being maintained, and so would exceptionally high mutation rates. An explanation based on possible pleiotropic effects of the recessive genes has been suggested to account for the frequent occurrence of heterozygosity at certain loci in plum cultivars (Williams and Brown, 1956). In the raspberry, however, it has already been postulated that linkage with a semilethal gene occurs in the case of both the $T$ and $H$ loci, and accounts for the observed aberrant segregation of these genes (Crane and Lawrence, I93 I; Grubb, 1935; Lewis, I939, I940). Consequently, if for each of these gene loci a second deleterious gene were found to 
be linked in repulsion or if the marker genes themselves were found to be linked together in such a way that the postulated lethal genes are in repulsion, then a balanced lethal system or systems would be present, and heterozygosity for the chromosome within which the genes are

TABLE I

Evidence of allelic diversity for genes $\mathrm{H}: \mathrm{h}$ (hairy:non-hairy canes) and $\mathrm{T}: \mathrm{t}$ (presence:absence of red pigment) in wild raspberry populations and in raspberry cultivars

\begin{tabular}{|l|c|c|c|}
\hline Material & $\begin{array}{c}\text { No. breeding } \\
\text { true for gene } T\end{array}$ & $\begin{array}{c}\text { No. segregating } \\
\text { for genes } T: t\end{array}$ & $\begin{array}{c}\text { No. breeding } \\
\text { true for gene } t\end{array}$ \\
\hline $\begin{array}{c}\text { Wild raspberry seed samples } \\
\text { Cultivated red raspberry varieties* }\end{array}$ & $\begin{array}{r}\text { I I } \\
7\end{array}$ & $\begin{array}{l}\text { I } 3 \\
\text { I6 }\end{array}$ & I \\
\hline Material & $\begin{array}{c}\text { No. breeding } \\
\text { true for gene } H\end{array}$ & $\begin{array}{c}\text { No. segregating } \\
\text { for genes } H: h\end{array}$ & $\begin{array}{c}\text { No. breeding } \\
\text { true for gene } h\end{array}$ \\
\hline $\begin{array}{c}\text { Wild raspberry seed samples } \\
\text { Cultivated hairy-cane raspberry } \\
\text { varieties* }\end{array}$ & 7 & I 7 & I \\
\hline
\end{tabular}

* Excludes varieties bred by distant hybridisation.

linked would tend to be maintained. Some evidence for the existence and consequences of this situation is presented here, together with some evidence in the case of the $H$ locus that the kind of selection differs in different situations with the result that different genotypes are favoured.

\section{MATERIAL AND METHOD}

Gene segregation was recorded in a large number of families whose parents were as follows:

I. Hybrids from reciprocal crosses between Burnetholm Seedling and Malling

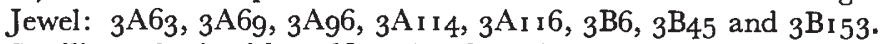

2. Seedlings obtained by selfing the above hybrids: $\mathrm{S}_{25 / 7}$ and $\mathrm{S}_{25} / 8$ (ex $3 \mathrm{~A} 69$ ), $\mathrm{S}_{29 / 97}$ (ex ${ }_{3} \mathrm{~B}_{45}$ ), and $\mathrm{S}_{32} / 99$ and $\mathrm{S}_{32 / 107}$ (ex ${ }_{3} \mathrm{~B}_{153}$ ).

3. A self of Burnetholm Seedling: ARI.

4. A hybrid from the cross between Burnetholm Seedling and Lloyd George: 5 I I/I 2 .

5. A hybrid from the cross between Malling Jewel and Baumforth's Seedling B: $4 \mathrm{~B}_{1} 5$.

6. A hybrid from the cross between Malling Exploit and Malling 64/53: I5/ro8.

7. The cultivars Burnetholm Seedling, Lloyd George, Norfolk Giant, Preussen, Malling Jewel and Malling M. Burnetholm Seedling is a " chance" seedling originating in Scotland. Because both the variety and its self (ARI) showed little inbreeding depression when selfed, the variety is considered to be derived from a wild population of narrow genetic base (Jennings, 1963). Norfolk Giant may also be of this type, but the other varieties showed little tolerance of inbreeding and are either known or postulated to be derived from wider crosses.

Field-grown seedlings were classified in the season after planting, when the contrasting phenotypes are easily recognised in the new growth (plate I). 


\section{SEGREGATION OF GENE $H$}

The segregation of genes $H$ and $h$ (table 2) frequently did not differ significantly from that expected, but sometimes there was a significant deficiency of the recessive allele and sometimes a significant excess.

TABLE 2

Variation in the segregation of genes $\mathrm{H}: \mathrm{h}$ in families derived by different breeding methods

\begin{tabular}{|c|c|c|c|c|c|c|}
\hline \multirow{2}{*}{ Parent(s)* } & \multirow{2}{*}{$\begin{array}{c}\text { Total } \\
\text { seedlings }\end{array}$} & \multirow{2}{*}{$\begin{array}{c}\% h \\
\text { pheno- } \\
\text { types }\end{array}$} & \multirow[b]{2}{*}{$\alpha_{2}$} & \multicolumn{3}{|c|}{ Reciprocal cross } \\
\hline & & & & $\begin{array}{c}\text { Total } \\
\text { seedlings }\end{array}$ & \begin{tabular}{c|}
$\% h$ \\
pherotypes
\end{tabular} & $\alpha_{2}$ \\
\hline \multicolumn{7}{|c|}{ (a) By selfing ( $25 \%$ of $h$ forms expected) } \\
\hline Bh.S & 494 & $28 \cdot I$ & $2 \cdot 59$ & $\ldots$ & $\ldots$ & $\ldots$ \\
\hline $3^{\mathrm{A} 69}$ & 49 & $4 \cdot 1$ & $11 \cdot 43$ & $\ldots$ & $\ldots$ & $\cdots$ \\
\hline $3{ }^{B} 63$ & 102 & $20 \cdot 6$ & $I \cdot 06$ & $\cdots$ & $\ldots$ & $\cdots$ \\
\hline $3^{\mathrm{B} 6}$ & 174 & $27 \cdot 0$ & $0 \cdot 3^{8}$ & $\cdots$ & $\cdots$ & $\cdots$ \\
\hline $\mathrm{S}_{25 / 7}$ & 66 & $10 \cdot 1$ & $7 \cdot 29$ & $\cdots$ & $\cdots$ & $\cdots$ \\
\hline L.George & 260 & $20 \cdot 4$ & $2 \cdot 95$ & $\cdots$ & $\cdots$ & $\cdots$ \\
\hline N.Wonder & $15^{8}$ & $32 \cdot 3$ & $4 \cdot 46^{* *}$ & $\cdots$ & $\cdots$ & $\cdots$ \\
\hline \multicolumn{7}{|c|}{ (b) By intercrossing heterozygotes ( $25 \% h$ forms expected) } \\
\hline $3^{A 69} \times$ Bh.S & 152 & $25 \cdot 7$ & $0 \cdot 03$ & 42 & $33 \cdot 3$ & $1 \cdot 56$ \\
\hline $3 \mathrm{~A} 69 \times 3 \mathrm{~B} 6$ & 194 & $22 \cdot 2$ & 0.83 & 181 & $28 \cdot 7$ & $1 \cdot 34$ \\
\hline $\mathrm{S}_{25 / 7} \times \mathrm{S}_{25 / 8}$ & 17 & $\mathrm{Ir} \cdot 8$ & $1 \cdot 59$ & 20 & $5 \cdot 0$ & $4 \cdot 27$ \\
\hline${ }_{3} \mathrm{~B} 6 \times \mathrm{Bh} . \mathrm{S}$ & 192 & $3^{8 \cdot 0}$ & $17 \cdot 36$ & 187 & $4^{1 \cdot 2}$ & $26 \cdot 10$ \\
\hline Bh.S × L.G. & 187 & $27 \cdot 8$ & $\mathbf{0} \cdot 79$ & 207 & $30 \cdot 0$ & $2 \cdot 71$ \\
\hline \multicolumn{7}{|c|}{ (c) By crossing between a heterozygote and homozygote $(50 \% h$ forms expected) } \\
\hline & $H h \times h h$ & & & & $h h \times H h$ & \\
\hline $\mathrm{Bh} . \mathrm{S} \times \mathrm{AR} \mathbf{I}$ & 497 & $47 \cdot 7$ & $1 \cdot 06$ & $57^{\circ}$ & $53 \cdot 7$ & $3 \cdot 10$ \\
\hline Bh.S $\times S_{32} / 99$ & 203 & $58 \cdot 6$ & 6.03 & 182 & $49 \cdot 5$ & 0.02 \\
\hline Bh.S $\times \mathrm{S}_{32 / 107}$ & 165 & $43 \cdot 3$ & $3 \cdot 21$ & 170 & $45 \cdot 3$ & $I \cdot 5^{I}$ \\
\hline Bh.S $\times 3 \mathrm{~B}_{45}$ & $33^{\circ}$ & $63 \cdot 6$ & $24 \cdot 54$ & 637 & $60 \cdot 3$ & $26 \cdot 94$ \\
\hline Bh.S $\times \mathrm{S}_{29 / 97}$ & 298 & $5^{6} \cdot 4$ & $4 \cdot 85$ & 378 & $53 \cdot 4$ & $1 \cdot 79$ \\
\hline $\mathrm{Bh} . \mathrm{S} \times 3_{3}^{\mathrm{Al}} 14$ & 229 & $57 \cdot 6$ & $5 \cdot 35$ & 197 & $5^{2 \cdot 6}$ & $0.6 \mathrm{r}$ \\
\hline Bh.S $\times$ N.G. & 187 & $6 r \cdot o$ & $8 \cdot 99$ & 181 & $5^{1 \cdot 4}$ & $1 \cdot 3^{8}$ \\
\hline Bh. $\mathrm{S} \times 4^{\mathrm{B}}{ }_{5}$ & 167 & $3^{I \cdot I}$ & $23 \cdot 77$ & 113 & $20 \cdot 4$ & $39 \cdot 73$ \\
\hline Bh.S $\times 511 / 12$ & 292 & $3^{r \cdot 1}$ & $41 \cdot 44$ & 360 & $30 \cdot 8$ & $52 \cdot 90$ \\
\hline 3A69 $\times$ M.Jw. & 184 & $45 \cdot 7$ & $\mathrm{I} \cdot 39$ & 163 & $43 \cdot 6$ & $2 \cdot 71$ \\
\hline $3 \mathrm{~B} 6 \times \mathrm{M} . \mathrm{Jw}$. & 204 & $4^{2 \cdot 2}$ & $5 \cdot 02$ & 135 & $57 \cdot 0$ & $2 \cdot 67$ \\
\hline $3 \mathrm{~B} 6 \times 3^{\mathrm{B}} 45$ & 121 & $43 \cdot 0$ & $2 \cdot 39$ & 122 & $42 \cdot 6$ & $2 \cdot 66$ \\
\hline${ }_{3} \mathrm{~B} 6 \times \mathrm{N} \cdot \mathrm{G}$ & 180 & $62 \cdot 8$ & $11 \cdot 76$ & I 79 & $45 \cdot 3$ & $\begin{array}{r}1 \cdot 62 \\
1 \cdot .6\end{array}$ \\
\hline $\mathrm{S}_{11 / 12 \times A R I}$ & $5^{12}$ & $62 \cdot 9$ & $34 \cdot 03$ & 525 & $64 \cdot 0$ & $41 \cdot 16$ \\
\hline $\mathrm{S}_{11} 1 / 12 \times \mathrm{S}_{29 / 97}$ & $33^{\circ}$ & $53 \cdot 6$ & $1 \cdot 75$ & $14^{1}$ & $50 \cdot 3$ & 0.01 \\
\hline $\mathrm{S}_{25} / 8 \times 15 / 108$ & 109 & $52 \cdot 3$ & 0.23 & 103 & $47 \cdot 6$ & $0 \cdot 24$ \\
\hline $\mathrm{S}_{25 / 7} \times \mathrm{S}_{29 / 97}$ & $\cdots$ & $\cdots$ & $\cdots$ & 53 & $62 \cdot 3$ & $3 \cdot 19$ \\
\hline
\end{tabular}

* Bh.S = Burnetholm Seedling; L.G. = Lloyd George; N.Wonder = Norwich Wonder; M.Jw. = Malling Jewel; N.G. = Norfolk Giant.

** Crane and Lawrence (1931).
Chi-square values of 3.84 and 6.64 show significant deviations from the ratio expected with probabilities of $0 \cdot 05$ and $0 \cdot 01$ respectively.

The parent $3 \mathrm{A6} 9$ and its two derivatives $\left(\mathrm{S}_{25} / 7\right.$ and $\mathrm{S}_{25} / 8$ ) gave very large deficiencies of gene $h$ when selfed or sibbed, but normal ratios when crossed with more distantly related parents. A simple way to explain this result would be to find a recessive lethal linked with gene $h$ in these parents but not in the others. It is therefore interesting that simple-leaved seedlings (plate $\mathrm{I} d$ ) segregated in these inbred families, 
and in two of them-containing altogether I4 I seedlings - their segregation showed only a small though significant deviation from the $3: \mathrm{I}$ ratio expected if it were due to the presence of a recessive gene, designated gene $s l$. As well as being deficient in occurrence, these seedlings did not survive long enough to be classified for hairiness, but clearly the results would be explained if genes $h$ and $s l$ were linked. Reciprocal crosses between Burnetholm Seedling and either ${ }_{4} \mathrm{BI} 5,5 \mathrm{II} / \mathrm{I} 2$ or $\mathrm{S}_{32 / 107}$ gave deficiencies of gene $h$, but other crosses with Burnetholm Seedling more frequently gave an excess. Reciprocal families often differed considerably in the degree of deviation recorded. In the families derived from crosses between ${ }_{3} \mathrm{~B} 6$ and either Malling Jewel or Norfolk Giant there was a suggestion that gene $h$ was deficient with one direction of crossing and in excess with the other.

TABLE 3

Variation in the segregation of genes $\mathrm{H} / \mathrm{h}$ in families raised in different seasons

\begin{tabular}{|c|c|c|c|c|c|}
\hline \multirow{2}{*}{ Cross } & \multirow{2}{*}{$\begin{array}{c}\text { Year of } \\
\text { cross }\end{array}$} & \multirow{2}{*}{$\begin{array}{l}\text { No. of } \\
\text { seedlings }\end{array}$} & \multicolumn{2}{|c|}{$\begin{array}{c}\% h \\
\text { seedlings }\end{array}$} & \multirow{2}{*}{$\alpha_{2} *$} \\
\hline & & & Obtained & Expected & \\
\hline Bh.S. $(H h)$ selfed & $\begin{array}{l}\text { I } 956 \\
\text { I } 962 \\
\text { I } 964\end{array}$ & $\begin{array}{r}84 \\
138 \\
272\end{array}$ & $\begin{array}{l}11 \cdot 9 \\
29 \cdot 7 \\
3^{6 \cdot 7}\end{array}$ & $\begin{array}{l}25.0 \\
25.0 \\
25.0\end{array}$ & $\begin{array}{c}7 \cdot 68 \\
1 \cdot 63 \\
20 \cdot 1\end{array}$ \\
\hline $\mathrm{AR}_{\mathrm{I}}(h h) \times 5 \mathrm{II} / 12(H h)$ & $\begin{array}{l}1962 \\
1964\end{array}$ & $\begin{array}{l}167 \\
35^{8}\end{array}$ & $\begin{array}{l}74 \cdot 9 \\
58 \cdot 9\end{array}$ & $\begin{array}{l}50 \cdot 0 \\
50 \cdot 0\end{array}$ & $\begin{array}{l}4^{1} \cdot 25 \\
11 \cdot 44\end{array}$ \\
\hline $511 / 12(H h) \times \mathrm{AR}_{1}(h h)$ & $\begin{array}{l}1962 \\
1964\end{array}$ & $\begin{array}{l}149 \\
363\end{array}$ & $\begin{array}{l}82 \cdot 6 \\
54 \cdot 8\end{array}$ & $\begin{array}{l}50 \cdot 0 \\
50 \cdot 0\end{array}$ & $\begin{array}{r}63 \cdot 15 \\
3 \cdot 37\end{array}$ \\
\hline
\end{tabular}

* Values of 3.84 and 6.64 show significant deviations with probabilities of 0.05 and 0.01 respectively.

Considering the crosses between heterozygotes and homozygotes, it is clear that deviations from the expected ratios were not consistently better or worse when the heterozygote was used as the pollen parent. This suggests that genotypes were lost after fertilisation, and that selection of the alternative embryo forms was possibly determined by their interaction with surrounding tissues such as the endosperm or nucellus, which are of different constitution in reciprocal crosses. That other environmental factors influenced this survival was suggested by variation in the results obtained for crosses or selfs which were repeated in different years. Three notable examples are given in table 3: the self of Burnetholm Seedling for example give a significant deficiency of $h$ genotypes in 1956, normal segregation in 1962 and a significant excess of $h$ forms in I964; and reciprocal crosses between AR I and 5 I I/ 12 each gave a far greater excess of $h$ forms in 1962 than in I 964 .

Lewis ( 1940 ) used the symbol $w$ to designate a lethal gene affecting segregation of genes $T$ and $t$. It is now proposed to designate this gene $w t$, and to use $w h$ for a lethal affecting genes $H$ and $h$. Another 
lethal affecting segregation at the $S: s$ locus is designated ws and will be described in a later paper.

\section{SEGREGATION OF GENE T}

Lewis (I 940) reported that aberrant ratios occurred when a plant of genotype $T t$ was used as pollen parent in crosses with the homozygote $(t t)$, but not when the reciprocal crosses were made. He attributed the aberrant segregation to linkage of gene $t$ with a gene which inhibits or prevents pollen-tube growth. He also reported that segregation of gene $t$ in Burnetholm Seedling was apparently normal and suggested

TABLE 4

Variation in the segregation of genes $\mathrm{T}$ :t in families derived by different breeding methods

\begin{tabular}{|c|c|c|c|c|c|c|}
\hline \multirow[b]{2}{*}{ Parent(s) } & \multirow{2}{*}{$\begin{array}{c}\text { Total } \\
\text { seedlings }\end{array}$} & \multirow{2}{*}{$\begin{array}{c}\% t \\
\text { forms }\end{array}$} & \multirow[b]{2}{*}{$\alpha 2$} & \multicolumn{3}{|c|}{ Reciprocal cross } \\
\hline & & & & $\begin{array}{c}\text { Total } \\
\text { seedlings }\end{array}$ & $\begin{array}{c}\% t \\
\text { forms }\end{array}$ & $\alpha 2$ \\
\hline \multicolumn{7}{|c|}{ (a) By selfing or intercrossing heterozygotes ( $25 \%$ of $t$ forms expected) } \\
\hline $\begin{array}{l}\text { Bh.S. } \\
\text { ARI } \\
\text { Bh.S. ×AR I } \\
\text { Ll.G. } \\
\text { Bh.S. × Ll.G. }\end{array}$ & $\begin{array}{r}494 \\
90 \\
497 \\
250 \\
207\end{array}$ & $\begin{array}{l}2 I \cdot 7 \\
I 6 \cdot 7 \\
20 \cdot 9 \\
I 4 \cdot 8 \\
\text { I I } \cdot I\end{array}$ & $\begin{array}{r}2 \cdot 94 \\
3 \cdot 33 \\
4 \cdot 40 \\
13 \cdot 87 \\
21 \cdot 30\end{array}$ & $\begin{array}{l}\ldots \\
\ldots \\
570 \\
\ldots \\
107\end{array}$ & $\begin{array}{c}\cdots \\
\cdots \\
22 \cdot 10 \\
\cdots \\
15 \cdot 51\end{array}$ & $\begin{array}{l}\cdots \\
\cdots \\
2 \cdot 55 \\
\ldots \\
8 \cdot 99\end{array}$ \\
\hline \multicolumn{7}{|c|}{ (b) By crossing between a heterozygote and a homozygote ( $50 \%$ of $t$ forms expected) } \\
\hline $\begin{array}{l}\text { Bh.S } \times \mathrm{S}_{32 / 99} \\
\text { Bh.S } \times \mathrm{S}_{32 / 107} \\
\text { Bh.S } \times 3_{9} \mathrm{~A}^{6} \\
\text { Ll.G. } \times{ }_{3 \mathrm{Ag} 6}\end{array}$ & $\begin{array}{l}T t \times t t \\
203 \\
165 \\
178 \\
232\end{array}$ & $\begin{array}{l}44 \cdot 3 \\
40 \cdot 0 \\
36 \cdot 0 \\
43 \cdot 5\end{array}$ & $\begin{array}{r}2 \cdot 61 \\
6 \cdot 60 \\
14 \cdot 04 \\
3 \cdot 88\end{array}$ & $\begin{array}{l}182 \\
168 \\
182 \\
204\end{array}$ & $\begin{array}{c}t t \times T t \\
45 \cdot I \\
55 \cdot 3 \\
42 \cdot 9 \\
3 I \cdot 4\end{array}$ & $\begin{array}{r}I \cdot 78 \\
I \cdot 9 I \\
3 \cdot 7 I \\
28 \cdot 3 I\end{array}$ \\
\hline
\end{tabular}

* Values of 3.84 and 6.64 show significant deviations with probabilities of 0.05 and 0.01 respectively.

that the pollen lethal was not present in this variety. The present results do not support these conclusions, however, because deficiencies of unpigmented $(t t)$ types occurred whichever way the crosses were made. They occurred too in crosses involving Burnetholm Seedling and ARI, a self of this variety, though the magnitude of the deficiencies when heterozygotes were used as pollen parents tended to be less for crosses involving Burnetholm Seedling than for those involving Lloyd George. Some results are given in table 4. Considerable differences also occurred in the segregation of gene $t$ in reciprocal crosses between parents of different origins, but in which both parents were heterozygous for this gene. These results suggest that either the viability of both gametes was affected by the gene, or that embryos of the recessive genotype were lost as well.

Several hypotheses might explain why the pollen is affected differentially in Lloyd George but not in Burnetholm Seedling. If for example there is allelic diversity at the wt locus (Lewis's gene w), it is possible that the two alleles present in Burnetholm Seedling are more 
equal in their effect than the two present in Lloyd George. On the other hand, if pollen competition is not the main factor, the result could be explained if the alleles present in Burnetholm Seedling mostly affected processes other than pollen growth, or if segregation in this variety was affected by a gene which is non-allelic to gene wt. It may be relevant that a parallel situation exists in the segregation of genes $S / s$, which in Burnetholm Seedling itself are linked with a gene having a large effect on the pollen and a small effect on either the egg or embryo, but in derivatives of this variety the small effects occur without the large effect on the pollen. Genes $T$ and $S$ are linked (see below), but more than one lethal must be involved because aberrant segregations at the $T / t$ and $S / s$ loci frequently occur independently of each other; nevertheless, some of the aberrant segregation recorded for either of these marker genes is undoubtedly due to the presence of the lethal associated with the other.

\section{THE EFFECT OF AUXIN ON SEGREGATION OF GENES $H$ AND $T$}

Eleven of the families studied formed part of an experiment to study the effect of auxin on seed development. In this experiment, auxin was brushed onto alternate green fruits on the fruiting laterals 7 days after pollination. There were four laterals per cross and the auxin was 50 p.p.m. of equal parts betanaphthoxyacetic acid and parachlorophenoxyacetic acid. The auxin had a significant effect on the segregation of genes $H$ and $T$ in only one of the eleven families, but there was a trend in two others which are closely related (table 5). It is interesting that in the cross Burnetholm Seedling $\times 511 / 12$ the treatment caused a change from normal segregation of genes $H$ and $h$ to an excess of the recessive, whereas in the other crosses it tended to reduce the proportion of this form, though the difference here is not significant. With gene $t$ the hormone treatment reduced the deficiencies of the recessive in each case. The effect of the treatment on seed development will be reported elsewhere, but it is relevant to note that endosperm size was increased in the Burnetholm Seedling $\times$ 5 I I / 2 cross but decreased in the others-a result which suggested that endosperm development required an optimum concentration of growth substance and that this differed in the different parental combinations. If this is so, one might speculate that the $W h$ locus is concerned with the production of a natural hormone which is produced in smaller amounts in the presence of the recessive allele: the recessive is therefore favoured when an auxin application produces a supraoptimal concentration, as may have been the case in the crosses between $5^{\mathrm{Ir} / \mathrm{r}_{2}}$ and either $\mathrm{ARr}$ or Burnetholm Seedling. Whatever the explanation, the fact that segregation of genes $H$ and $T$ can be influenced by a treatment applied 7 days after pollination suggests that aberrant ratios in these crosses were caused by differences in the viability of embryos and as well as gametes. 


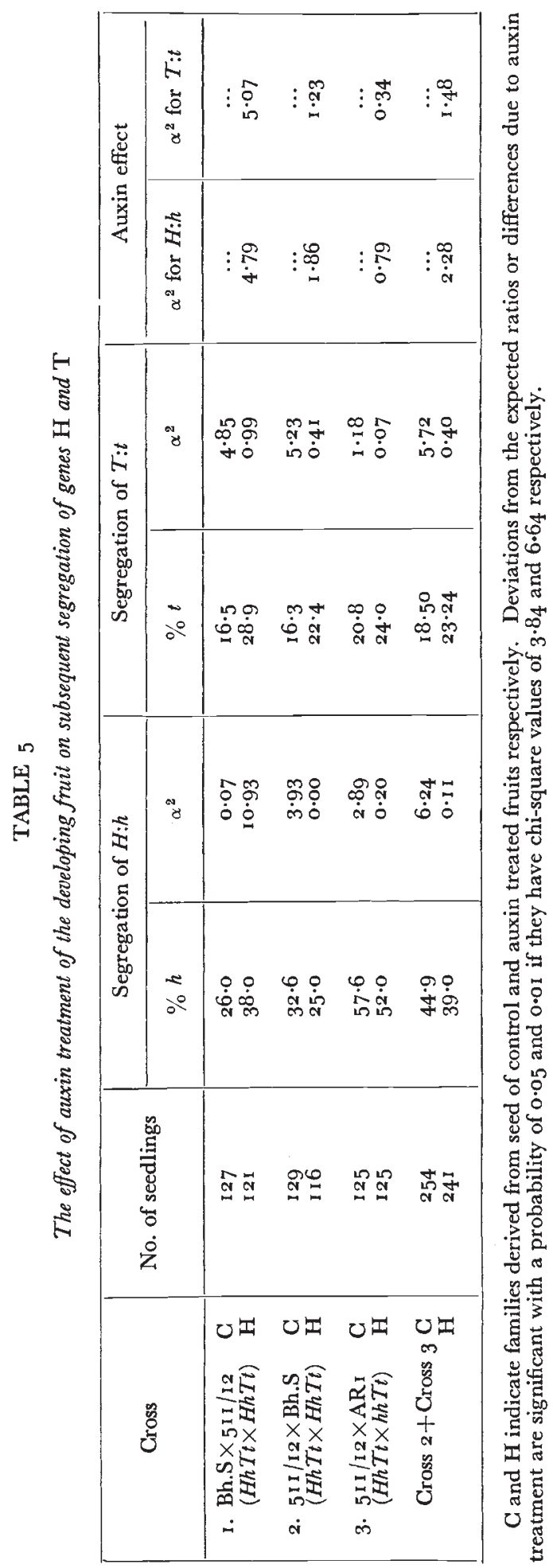




\section{LINKAGE OF GENES $H$ AND $T$}

It was suggested early in this paper that a balanced lethal system would be present if genes $H$ and $T$ were linked together in such a way that the lethal genes associated with them were linked in repulsion. Alternatively, the two genes may be linked with other lethals or semilethals. Three such lethals which can be considered are gene ws, which causes aberrant segregation at the $S$ locus; a semi-lethal gene designated $d w$ (plate $\mathrm{I} d$ ) which causes weak dwarf plants, and gene $s l$ discussed above. Five pairs of reciprocal crosses which were segregating for genes $H, T$ and $S$ were examined for evidence of two of these possibilities. The amount of linkage present between two genes is usually estimated by considering the relative proportion of recombinant phenotypes, but this method assumes equal viability of the recombinant and parental types. However, if semi-lethals are linked with the marker genes, the lower frequency of formation of recombinant genotypes may be offset by their greater survival value: indeed, if the lethals are fully effective only recombinant genotypes will survive. It is clearly not possible to estimate the amount of linkage present in these circumstances, but for present purposes it is sufficient to establish its presence, and this is done here by chi-square tests for significant deviations from the expected ratios which can be attributed to joint segregation of the genes. The data (table 6) show evidence of deviations due to joint segregation between genes $H$ and $T$ and between genes $T$ and $S$, but deviations due to the joint segregation of genes $H$ and $S$ are so slight that they are significant only in the combined data.

Comparison of the data with the expectation if the surviving genotypes had combined at random (table 7) shows that the dominant and recessive combinations are in excess. Thus all the genes must be linked in coupling and their order along the chromosome must be $H-T-S$. In Burnetholm Seedling the semi-lethal genes are associated with genes $t, s$ and $H$. The $H$ and $T$ loci can therefore be regarded as part of a balanced lethal system. The semi-lethals associated with the $S$ and $T$ loci are in coupling and not repulsion, so they will tend to complement each other in effect, but they would form a second balanced lethal system if a cross-over occurred and resulted in the lethal becoming associated with the $S$ allele. However, when Burnetholm Seedling is used as the seed parent in crosses, it is frequently the $S$ allele which is in excess, but only by relatively small amounts. If this deviation is caused by the same gene that affects the pollen (gene ws), then again a second balanced lethal system would be present. It is also possible, however, that the aberrant segregation is caused by the gene that affects segregation of gene $t$.

Since close linkage between the $T$ locus and the $B$ locus, which determines the presence or absence of a waxy bloom, has been reported previously (Lewis, I940; Keep, I964), the material was examined to find the position of the latter locus relative to that of $H$ and $S$. Segregation of gene $B$ was recorded among 2065 seedlings in three of the 


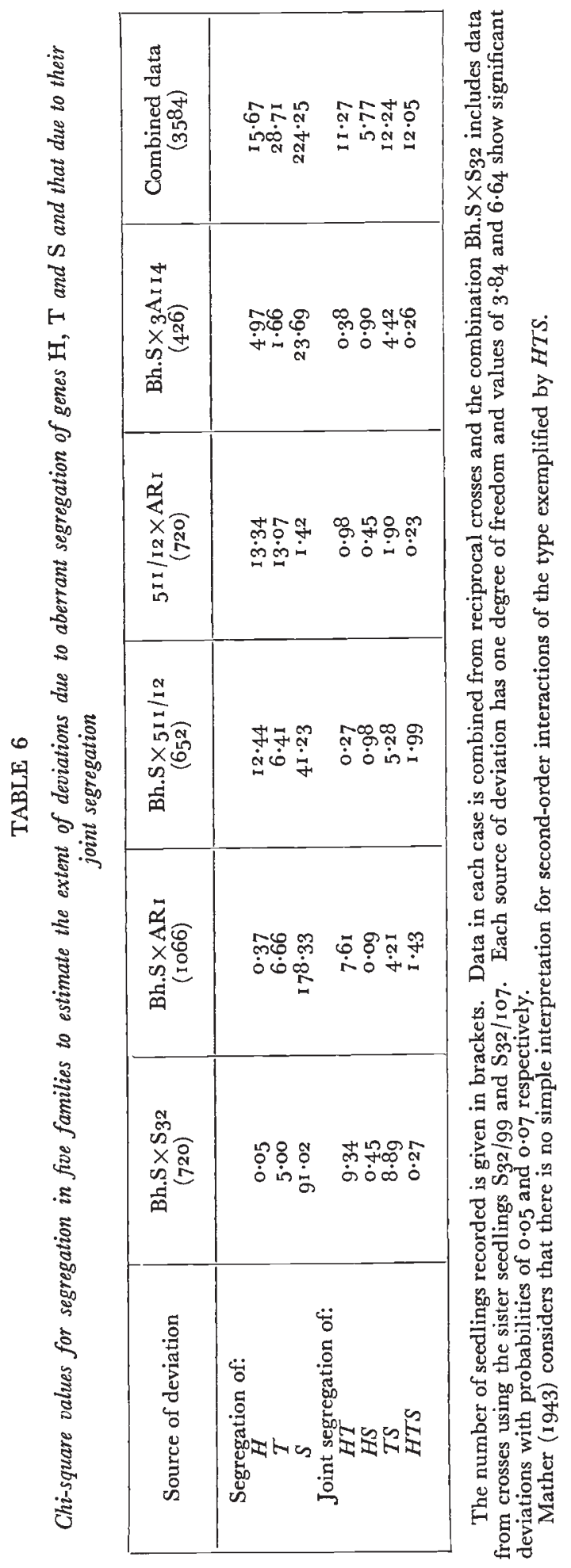


families described above, and the deviation due to joint segregation was greater for genes $B$ and $H\left(\alpha^{2}=32 \cdot 43\right)$ than for genes $B$ and $S$ $\left(\alpha^{2}=5 \cdot 43\right)$. The $B$ locus must therefore be between the $T$ and $H$ loci and distal to the $S$ locus.

\section{TABLE 7}

Segregation of genes $\mathrm{H}, \mathrm{T}$ and $\mathrm{S}$ in the material listed in Table 6 showing the expectation ( $\mathrm{I})$ if all genotypes had equal viability and segregation was at random $\left(E_{I}\right)$ and $(2)$ if the observed phenotypes had associated at random $\left(E_{2}\right)$ i.e. allowing for unequal viability but not for nonrandom segregation

\begin{tabular}{|c|c|c|c|}
\hline \multirow{2}{*}{ Phenotype } & \multirow{2}{*}{ No. observed } & \multicolumn{2}{|c|}{ No. expected } \\
\cline { 2 - 3 } & & $\mathbf{E}_{\mathbf{I}}$ & $\mathbf{E}_{\mathbf{2}}$ \\
\hline$H T S$ & Ior9 & $8 \mathrm{I} 9$ & 953 \\
$H T S$ & 400 & 557 & $4 \mathrm{IO}$ \\
$H t S$ & 288 & 334 & 333 \\
$h T S$ & 884 & 637 & 904 \\
$h t S$ & $3 \mathrm{I} 5$ & 272 & $3 \mathrm{I} 6$ \\
$h T s$ & 353 & 495 & 389 \\
$H t s$ & $\mathrm{I} 30$ & 245 & $\mathrm{I} 43$ \\
$h t s$ & 195 & 225 & $\mathrm{I} 36$ \\
\hline
\end{tabular}

\section{SEGREGATION AND LINKAGE OF A GENE FOR DWARFNESS}

Dwarf seedlings (plate $\mathrm{I} c$ ) segregated in several of the families studied and it appeared that this segregation was determined by a single recessive gene $(d w)$ linked in coupling to both gene $h$ and gene $t$ (table 8 ). The dwarfs were frequently very weak and linkage with this gene undoubtedly reduced the survival of $h$ and $t$ phenotypes in some families.

The families showed large deficiencies of dwarf genotypes when either gene $h$ or gene $t$ was deficient, but greater numbers of dwarfs when either of these two genes was segregating more normally; this is particularly so in the cross Malling Jewel $\times{ }_{3} \mathrm{~B} 6$ where $h$ forms occurred in excess of expectation. Since there was evidence of linkage between genes $H$ and $D w$ and between genes $T$ and $D W$, the full data are given in table 9 for the selfed progeny of seedling $3 \mathrm{~B} 6$, the only family segregating for each of these three genes.

Phenotypes HTDw and htdw were in excess, as would be expected if the genes are linked in coupling; and the occurrence of greater deficiencies of phenotypes $H d w T$ and $h D w t$ supports the suggestion that the $D w$ locus is situated between the other two genes, since their formation would then require double crossing over. In this family there were small excesses of $h$ and $T$ forms: thus, despite its being a cross-over type, phenotype $h D w T$ was in excess of expectation, presumably because the increased viability of genes $h$ and $T$ more than compensated for its less frequent formation. Cross-over values cannot be accurately evaluated, and again it is sufficient to note that the $D w$ locus is situated between the $H$ and $T$ loci. 
TABLE 8

Evidence for joint segregation (linkage) of genes $\mathrm{H}, \mathrm{T}$ and $\mathrm{Dw}$

\begin{tabular}{|c|c|c|c|c|c|c|c|}
\hline $\begin{array}{l}\text { Phenotype } \\
\text { material }\end{array}$ & \multicolumn{4}{|c|}{$\begin{array}{l}\text { Number of seedlings } \\
\text { obtained }\end{array}$} & \multicolumn{3}{|c|}{$\alpha^{2}$ for deviations in } \\
\hline \multicolumn{8}{|c|}{ (a) Genes $H$ and $D w$} \\
\hline & $H D w$ & $H d w$ & $h D w$ & $h w$ & $\begin{array}{c}H \\
\text { segregation }\end{array}$ & $\begin{array}{c}D w \\
\text { segregation }\end{array}$ & $\begin{array}{l}\text { Joint } \\
\text { segregation }\end{array}$ \\
\hline $\begin{array}{l}\text { 3A63 self } \\
3 \mathrm{~A} \text { I } 6 \text { self } \\
3 \mathrm{~B} 6 \text { self } \\
3 \mathrm{~B} 6 \times \mathrm{M} . J \text { Jewel } \\
\text { M.Jw. } \times 3 \mathrm{~B} 6\end{array}$ & $\begin{array}{r}76 \\
21 \\
\text { I I } \\
\text { I I } \\
34\end{array}$ & $\begin{array}{r}5 \\
2 \\
17 \\
8 \\
3\end{array}$ & \begin{tabular}{r|}
20 \\
2 \\
33 \\
72 \\
44
\end{tabular} & $\begin{array}{r}1 \\
1 \\
14 \\
10 \\
12\end{array}$ & $\begin{array}{l}I \cdot 06 \\
2 \cdot 51 \\
0 \cdot 38 \\
6 \cdot 48 \\
3 \cdot 88\end{array}$ & $\begin{array}{r}19 \cdot 88 \\
2 \cdot 51 \\
4 \cdot 79 \\
27 \cdot 31 \\
3 \cdot 90\end{array}$ & $\begin{array}{l}0 \cdot 11 \\
I \cdot 39 \\
4 \cdot 72 \\
3 \cdot 22 \\
1 \cdot 04\end{array}$ \\
\hline Total & $35^{1}$ & 35 & I 71 & $3^{8}$ & $I \cdot 2 I$ & $5^{I \cdot 43}$ & $7 \cdot 54$ \\
\hline \multicolumn{8}{|c|}{ (b) Genes $T$ and $D w$} \\
\hline & $T D w$ & $T d w$ & $t D w$ & $t d w$ & $\begin{array}{c}T \\
\text { segregation }\end{array}$ & $\begin{array}{c}D w \\
\text { segregation }\end{array}$ & $\begin{array}{l}\text { Joint } \\
\text { segregation }\end{array}$ \\
\hline $\begin{array}{l}\text { Preussen self } \\
\text { Malling M self } \\
\text { 3A I } 4 \text { self } \\
3^{\mathrm{B} 6} \text { self }\end{array}$ & $\begin{array}{r}54 \\
88 \\
44 \\
\text { I } 7 \\
\end{array}$ & $\begin{array}{r}3 \\
4 \\
12 \\
15 \\
\end{array}$ & $\begin{array}{l}\text { II } \\
22 \\
13 \\
26 \\
\end{array}$ & $\begin{array}{r}0 \\
0 \\
5 \\
16\end{array}$ & $\begin{array}{l}2 \cdot 82 \\
1 \cdot 98 \\
0.02 \\
0.07 \\
\end{array}$ & $\begin{array}{r}15 \cdot 37 \\
28 \cdot 08 \\
0 \cdot 16 \\
4 \cdot 79 \\
\end{array}$ & $\begin{array}{r}0.24 \\
0.10 \\
0.29 \\
12 \cdot 16\end{array}$ \\
\hline Total & 303 & 34 & 72 & 21 & $2 \cdot 6 I$ & $34 \cdot 19$ & $7 \cdot 82$ \\
\hline
\end{tabular}

* See footnote to Table 5 .

TABLE 9

Segregation of genes $\mathrm{H}, \mathrm{T}$ and $\mathrm{Dw}$ in a family obtained by selfing ${ }_{3} B 6$

\begin{tabular}{|l|r|r|}
\hline \multirow{2}{*}{ Phenotype } & \multicolumn{2}{|c|}{ No. of plants } \\
\cline { 2 - 3 } & Obtained & Expected \\
\hline & & \\
\hline$H D w T$ & & \\
$H D w t$ & 90 & $73 \cdot 2$ \\
$H d w T$ & 19 & $24 \cdot 5$ \\
$h D w T$ & 12 & $24 \cdot 5$ \\
$h d w T$ & 27 & $24 \cdot 5$ \\
$h D w t$ & 7 & $8 \cdot 2$ \\
$H d w t$ & 3 & $8 \cdot 2$ \\
$h d w t$ & 6 & $8 \cdot 2$ \\
& 10 & $2 \cdot 7$ \\
\hline
\end{tabular}

\section{SHELTERING OF RECESSIVE GENES}

A consequence of a situation where a chromosome segment tends to remain heterozygous is that recessive genes carried by it are exposed to selection less frequently than normally. Deleterious genes may not persist sufficiently to form polymorphic populations, but nevertheless their survival may be prolonged, and in Rubus idaus it seems that mutant 
forms of wild-type genes are retained more frequently when they are in the same linkage group as genes $H$ and $T$. In fact, of the $I 7$ genes discovered which affect morphological features of the raspberry, 9 have been shown to be situated on the chromosome in question (Lewis, r939; Keep, r964; Jennings, unpublished); gene $S 1$ may also be on this chromosome and the linkage relationships of the remainder $\left(M, F, C, F r, P, L_{\mathbf{I}}\right.$ and $\left.L_{2}\right)$ are largely unknown. Six of these linked loci are heterozygous in Burnetholm Seedling. The recessive forms of each of the nine genes mentioned $\left(h, d w, c r, b, s x_{3}, t, g, x\right.$, and $s$ ) have deleterious effects on either plant survival or reproductive capacity: gene $d w$, which determines dwarfness considerably reduces plant vigour; gene $h$ renders mature canes more liable to attack by certain fungal pathogens; gene $b$ has this effect too, and also reduces cane hardiness (Jennings, I962); genes $s \times 3$ (Keep, I964) and $c r$ (Jennings, to be published) reduce fertility; gene $g$ probably reduces photosynthetic efficiency; gene $t$ gives yellow fruits which are less attractive to birds and hence less likely to have their seeds disseminated; and gene $s$ gives the canes less protection against pests. It is tempting to speculate, therefore, that the survival of each of these recessive genes would be more short-lived if it were not for their partial concealment from selection pressure.

\section{DISCUSSION}

The data presented provide good evidence for the occurrence and wide distribution of a balanced lethal system in Rubus idcus. This could have many of the consequences to the breeding system that are commonly attributed to the presence of chromosome inversions or to heterozygosity for reciprocal chromosome translocations. Heterozygosity, for example, would tend to be maintained, and the necessity for outbreeding reduced if important gene complexes are situated on the chromosome carrying the lethal genes. If this is so, the property of maintaining successful combinations of genes would be particularly advantageous where small but distinct populations of wild raspberries persist in comparative isolation (Jennings, r964).

The existence of these kinds of breeding mechanism are difficult to detect. In this material, for example, detection of the balanced lethal system depended on the occurrence of marker genes, in Drosophila the widespread detection of chromosome inversions was possible only because of the peculiarities of the salivary gland chromosomes, while the frequency of plant populations heterozygous for reciprocal translocations did not become apparent until the advent of cytological surveys (Jones, 1957). In Vicia faba only circumstantial evidence indicates that balances lethal systems might be present; their presence has also been suggested as the means of maintaining tolerance to inbreeding in Medicago sativa, Melilotus officinalis and Theobroma cacao (Rowlands, rg6o, r964).

If a balanced lethal system survives for a long period the survival 
value of plants homozygous for the chromosome involved will be progressively lowered, because genes which are non-adaptive in the homozygous state will be sheltered from selection and will tend to accumulate. The accumulation of non-adaptive recessive genes in the linkage group studied here is a good indication of this. Consequently, it is possible that the genetic situation may slow the progress of improvement programmes involving inbreeding; alternatively, if the genes which the breeder seeks to make homozygous are not located on the chromosome containing the lethals-possibly genes affecting fruit quality, which are not of adaptive value in nature-the same genetic mechanism may facilitate progress by keeping important adaptive genes heterozygous and thereby avoiding inbreeding depression. It is in fact known that some raspberry varieties-notably Burnetholm Seedling and others believed to be closely related to wild populations - tolerate inbreeding, but it is not clear whether this tolerance has been built up merely by the smallness of the breeding populations from which the varieties were derived, or whether it is mediated by a mechanism such as the one described here in which heterozygosity is maintained.

The families studied showed considerable variation in the survival value of the two forms identified by the marker genes $H$ and $h$. Two possible explanations for this depend on whether the dominant phenotypes recorded are predominantly heterozygous $(H h)$ or include an excess of the homozygote $(H H)$ as well. Preponderance of the dominant $(H)$ phenotype could result merely from intensive selection of the heterozygous $(H h)$ genotype, while an excessive proportion of the recessive $(h)$ form could result simply from a change in selection pressure allowing the homozygous recessive $(h h)$ but not the homozygous dominant $(H H)$ to survive as well. This might occur, for example, if a gene near the $H$ locus were concerned in the production of a substance optimal concentration was optimal where the gene was heterozygous $(H h)$ but was more favourable in the presence of $h h$ than $H H$. It is likely that selection pressure would be most intense and hence would discriminate most strongly in favour of the heterozygote where close inbreeding leads to reduction in embryo size (Topham, to be published). This model therefore suggests a mechanism for regulating the relative frequencies with which heterozygotes survive according to the degree to which the parent is inbred. Such regulation has been described in Vicia faba (Drayner, I959) and in Medicago corulea (Fyfe, I957).

Alternatively, the relative survival value of the alleles when homozygous may be affected by environmental conditions and this may explain variations in departure from expected segregation ratios. It is probable that embryos must be balanced in their development with the development of the surrounding seed tissues, and it is conceivable that in different situations different alleles may better achieve this, an idea which has been proposed to explain variations in the survival 
of alleles at the $S$ locus in blackberries (Jennings, Craig and Topham, I 967 ).

\section{SUMMARY}

I. Populations of wild raspberries in Britain are usually polymorphic for the presence or absence of cane hairs, determined by genes $H$ and $h$, and sometimes for the presence or absence of plant pigment, determined by genes $T$ and $t$. A high proportion of raspberry cultivars also are heterozygous for these two genes.

2. The aberrant segregation ratios associated with each of these loci can be attributed to their linkage with lethal genes in such a way that the lethals form a balanced system.

3. Since the lethal system confers a selective advantage on the heterozygote, it is probably responsible for the polymorphism and allelic diversity, and also for the relatively high frequency of recessive deleterious genes in this linkage group. But in the case of the $H$ locus, allelic diversity may also be maintained by the tendency of the dominant phenotype to be favoured in some cross-combinations and the recessive in others.

4. The presence of the lethal system helps raspberry populations to maintain heterozygosity for the particular chromosome segment and may help small populations to avoid inbreeding depression.

\section{REFERENCES}

GRANE, M. B., AND LAWRENCE, W. J. G. I 93 I. Inheritance of sex, colour and hairiness in the raspberry, Rubus ideus L. F. Genet., 24, 243.

DRAYNER, J. M. I959. Self and cross-fertility in field beans (Vicia faba). J. Agric. Sci., 53,387 .

FYFE, J. L. I957. Relational incompatibility in diploid and tetraploid lucerne. Nature, Lond., I79, 59 I.

GRUbB, N. H. I 922. Commercial raspberries and their classification. 7. Pomol., 3, I I -35 .

GrubB, N. H. 1935. Raspberry breeding at East Malling 1922-34. F. Pomol., 13, I $08-134$.

HASKELl, G. Ig6o. The raspberry wild in Britain. Watsonia, 4, 238.

JENNINGS, D. L. I962. Some evidence on the influence of the morphology of raspberry canes upon their liability to be attacked by certain fungi. Hort. Res., I, I OO-I I I.

JENNINGS, D. L. I963. Some evidence on the genetic structure of present-day raspberry varieties and some possible implications for further breeding. Euphytica, $12,229-243$.

JENNINGS, D. L. 1964. Some evidence of population differentiation in Rubus idaus $\mathbf{L}$. New Phytol., 63, I 53-I 57.

JENNINGS, D. L., GRAIG, D. L., AND TOPHAM, P. B. I967. The role of the male parent in the reproduction of Rubus. Heredity 22, 43-25.

JONES, K. 1957. Some aspects of plant variation-the grasses. In Progress in the Study of the British Flora, p. 45. Ed. J. E. Lousely.

KEEP, E. I964. Sepaloidy in the red raspberry, Rubus idaus L. Can. 7. Genet. Gytol. $6,52-60$.

LEWIS, D. I939. Genetical studies in cultivated raspberries. I. J. Genet., 38, $367-379$.

LEWIS, D. I940. Genetical studies in cultivated raspberries. II. Genetics, 25, 278-286. 


\section{Plate I}

(a) Portion of a hairy cane. Phenotype $H$.

(b) Portions of pigmented (left) and non-pigmented canes (right). Phenotypes $T$ and $t$.

(c) A dwarf seedling ex ${ }_{3} \mathrm{~B} 6$. Phenotype $d w$.

(d) A simple-leaved seedling ex ${ }_{3}$ A69. Phenotype $s l$. 


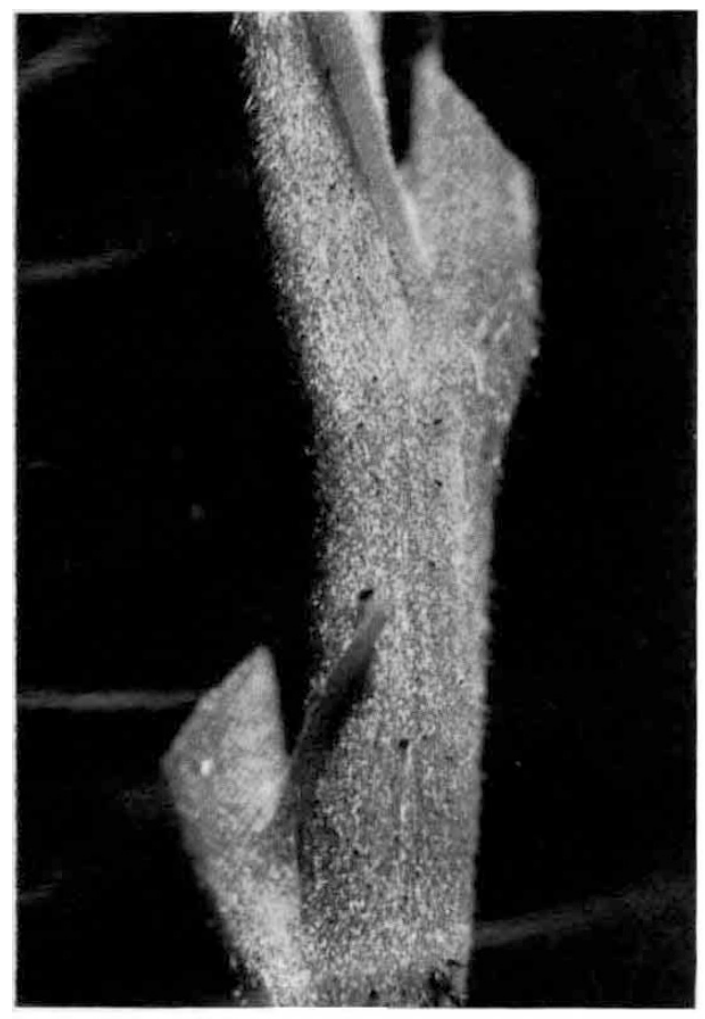

(a)

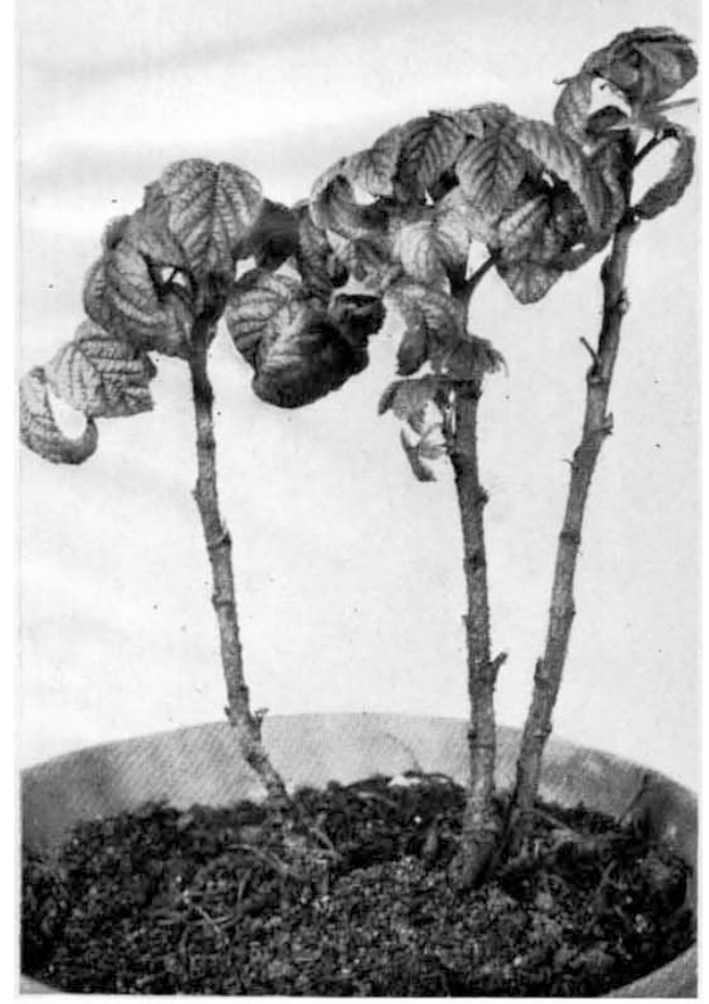

(c)
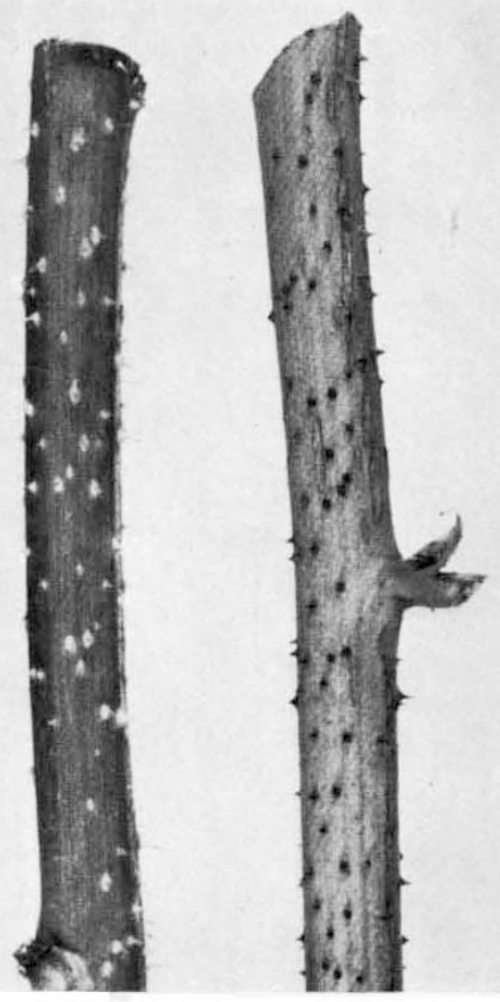

(b)

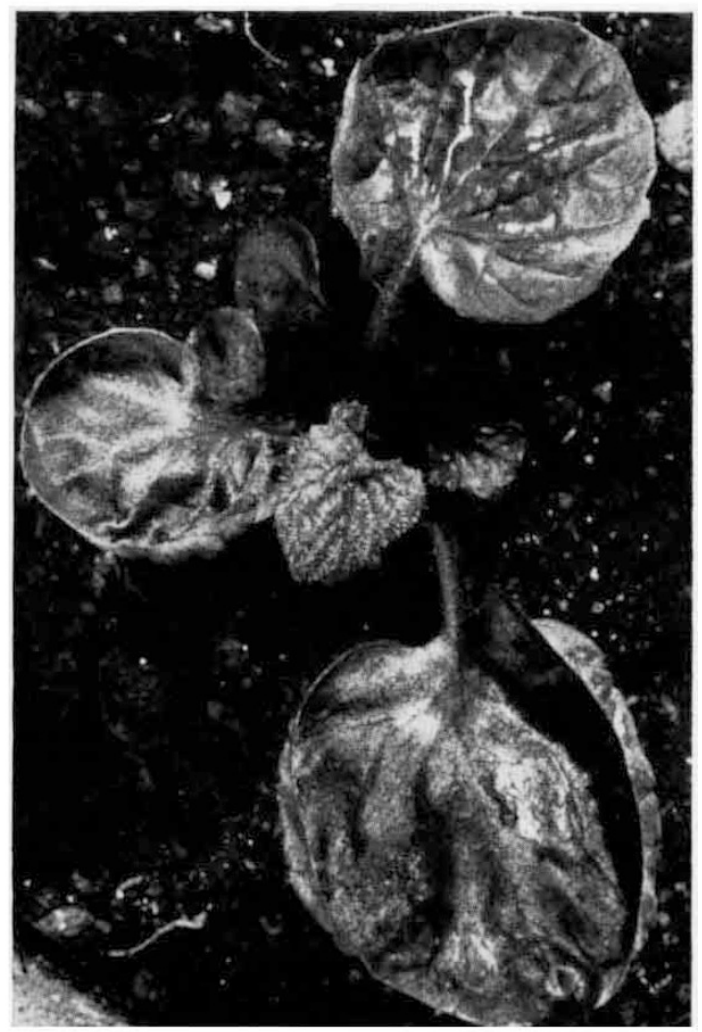

(d) 
MATHER, K. 1943. Statistical Analysis in Biology, p. 186. London: Methuen.

Rowlands, D. G. Ig6o. Fertility studies in the field bean (Vicia faba L.). I. Cross and self-fertility. Heredity, $15, \mathrm{I} 6 \mathrm{I}-\mathrm{I} 73$.

ROWLANDS, D. G. 1964. Self incompatibility in sexually propagated cultivated plants. Euphytica, 13, 157-162.

WILlIAMS, W., AND BROWN, A. G. 1956. Genetic response to selection in cultivated plants: gene frequencies in Prunus avium. Heredity, 10, 237-246. 